\title{
On the Implementation of Rural Ecological Tourism Community Participation Mode in Our Country
}

\author{
Yang dan \\ 1. School of Tourism, Sichuan University, Chengdu Sichuan 610065, China \\ 2. School of Foreign Languages, China West Normal University, Nanchong Sichuan 637002, China
}

Keywords: Rural Eco-tourism; Community participation; Mode; Implementation

\begin{abstract}
Community participation is the key point of rural Eco-tourism's connotative development, and the community is key stakeholder of rural Eco-tourism. This paper explores and researches the selection and application of rural ecological tourism community and participation mode, draws on the successful cases of domestic and foreign relevant experience, and makes implementable analysis with the starting point of domestic tourism market and its related interests. With the ongoing global economic integration process, the third service industry economy, dominated by tourism as a pillar industry, has also made rapid development. At present, in our country's domestic tourism market, rural tourism has become one of the themes of the new century, and the rural economic development in the new period. With the constant improvement of rural Eco-tourism industry pattern system, it not only drives all-round development of rural economy in our country, but more importantly put forward a new idea, a new road for the sustainable development of tourism industry in China. This paper selects some domestic cases of rural ecological tourism community, combines these classic cases for comparison and analysis, and finds out the suitable community participation model with local characteristics for our country's tourism development.
\end{abstract}

\section{RURAL ECOLOGICAL TOURISM COMMUNITY PARTICIPATION MODEL RESEARCH}

A. The relationship between rural Eco-tourism and community participation With the continuous development of social economy, people's living standard has been greatly improved, and then there is a new market demand for spiritual culture, which, in turn, helps the research and development of rural Eco-tourism community projects. Rural Eco-tourism's development is mainly to fully excavate the associated effects of area ecological scenic spots and the surrounding tourism landscape, and the main body of associated entities is the masses of neighborhood residents under the condition of common interests.

$B$. The selected target of rural tourism community participation

1. Rural ecological sustainable development

Pure and natural ecological environment is the basis of constructing rural ecological tourism community participation mode. If blindly develop without any restraint mechanism, it is bound to bring a series of negative effects for the development of rural Eco-tourism. Therefore, in the process of rural tourism project development, planning and design, uphold that local basic ecological process, ecological natural resources and biodiversity are coordinated. The local government and related social organizations should also earnestly strengthen the management mechanism, and effectively control the tourist hotel amount of rural ecological tourism development area.

2. Rural economic sustainable development

Rural ecological tourism community participation pattern choice's fundamental purpose is to comprehensively promote the development and prosperity of local society. The most important is the change of social economy development and economic increase way, while the development of rural Eco-tourism resources will greatly promote and improve the situation. Economic benefit is the objective of rural ecological tourism project development and construction, including enterprise economic benefit, social and economic benefit and local residents' income, etc. It should be an economy return of local rural tourism operators and related departments, and the important factor which maintains rural tourism market supply. I think in this respect, it is not inconsistent with the target selection for rural ecological sustainable development for rural tourism must also bring no less than the threshold visitors of community tourism project development, and all the benefits 
generated are used to maintain the level and scale of local tourism scenic area.

C. The selection principles of rural tourism community participation mode

1. The basic principles of adjusting measures to local conditions

The choice of rural tourism community participation mode must avoid by all means too new, and must hold to find out a suitable pattern for their development (see Table 2-1 "Comparative analysis of our country's rural ecological tourism community participation pattern type"). According to the objective standard, select suitable local development pattern. Regardless of what kind of pattern choice, the most critical factor is to adhere to the basic principle of adjusting measures to local conditions, and make full development and utilization of local infrastructure, tourism resources, cultural and historical background.

2. The basic principles of sustainable development

Sustainable development has been advocated social and economic development mode, and is taken as a strategic development project guideline. In the sustainable development principles of rural tourism, follow the idea of "human-oriented". Whether the construction of rural ecological tourism community or the development of social economy, the fundamental aim is to serve the people (meet the needs of tourists, and increase the income of the community). On the principle choice, therefore, maximally meet the specific needs of the local tourism without harm in the rights of travel demand of our children.

\section{OUR COUNTRY'S RURAL ECOLOGICAL TOURISM COMMUNITY PARTICIPATION PATTERN}

Table 2-1 Comparative analysis on our country's rural ecological tourism community participation pattern

\begin{tabular}{|c|c|c|c|}
\hline $\begin{array}{l}\text { Community } \\
\text { participation main } \\
\text { body mode }\end{array}$ & Operation mode & $\begin{array}{l}\text { Main representative } \\
\text { characteristics }\end{array}$ & Typical cases \\
\hline $\begin{array}{l}\text { Farmers } \\
\text { Farmers }\end{array}$ & $\begin{array}{l}\text { The community participation } \\
\text { pattern's main operation is } \\
\text { that farmers drive farmers, } \\
\text { and farmers are free to } \\
\text { combine with each other, and } \\
\text { set up a common } \\
\text { development goal; farmers } \\
\text { collectively develop, operate } \\
\text { and manage rural tourism. }\end{array}$ & $\begin{array}{l}\text { The biggest feature of this } \\
\text { community participation in } \\
\text { rural tourism is that it costs } \\
\text { less; with inadequate fund, } \\
\text { and technology, its regional } \\
\text { hotels and the corresponding } \\
\text { driving effects are very } \\
\text { limited. However, this model } \\
\text { retains the complete local } \\
\text { village culture. }\end{array}$ & $\begin{array}{l}\text { "Deer } \\
\text { creek"----Han } \\
\text { Shou county, } \\
\text { Hunan } \\
\text { province in } \\
\text { China }\end{array}$ \\
\hline $\begin{array}{l}\text { Farmers } \\
\text { Government }\end{array}$ & $\begin{array}{l}\text { The community participation } \\
\text { pattern is mainly } \\
\text { government-lead and } \\
\text { farmer-participate. The } \\
\text { government gives full play to } \\
\text { administrative function; } \\
\text { strengthen the management } \\
\text { mechanism of rural area } \\
\text { through planning and } \\
\text { establishment of the } \\
\text { company. The community } \\
\text { residents can participate in } \\
\text { the tourism projects. }\end{array}$ & $\begin{array}{l}\text { The community participation } \\
\text { model can greatly improve } \\
\text { rural tourism environment. } \\
\text { The government-led regional } \\
\text { market enhances the } \\
\text { absorption capacity of the } \\
\text { market, and some local } \\
\text { resident's employment and } \\
\text { income. However, its } \\
\text { outstanding problem is the } \\
\text { conflicts between legal and } \\
\text { illegal operators, plus factors } \\
\text { such as lagging policies and } \\
\text { poor managements, finally } \\
\text { may cause the fall of the } \\
\text { government's credibility. }\end{array}$ & $\begin{array}{l}\text { Sichuan } \\
\text { province in } \\
\text { China, Dan Ba } \\
\text { county ---- } \\
\text { Jiaju Tibetan } \\
\text { village ---- } \\
\text { Xijiang Miao } \\
\text { village }\end{array}$ \\
\hline
\end{tabular}




\begin{tabular}{|c|c|c|c|}
\hline $\begin{array}{l}\text { Farmers } \\
\text { company } \\
\text { community }\end{array}$ & $\begin{array}{l}\text { The community participation } \\
\text { pattern is mainly developed } \\
\text { by the company, including } \\
\text { planning, management, } \\
\text { management, etc., through } \\
\text { equal contract with the } \\
\text { farmers, establish } \\
\text { cooperation relations, and } \\
\text { appropriately clear the } \\
\text { liability relationship. }\end{array}$ & $\begin{array}{l}\text { In the community } \\
\text { participation pattern, the } \\
\text { company is responsible for } \\
\text { the integration of tourism } \\
\text { products and market } \\
\text { development, technology } \\
\text { innovation, and management } \\
\text { work; Advantages: promote } \\
\text { local social employment, and } \\
\text { greatly increase the } \\
\text { economic income of local } \\
\text { residents; Faults: community } \\
\text { participation is low, and } \\
\text { regional ecological tourism } \\
\text { features are not prominent; } \\
\text { tourism products lack } \\
\text { personality. }\end{array}$ & $\begin{array}{l}\text { Hunan } \\
\text { province in } \\
\text { China, } \\
\text { Liuyang } \\
\text { city---- "Zhong } \\
\text { Yuan peasant } \\
\text { house"----Dai } \\
\text { village in } \\
\text { Xishuangbanna }\end{array}$ \\
\hline $\begin{array}{l}\text { Community } \\
\text { residents } \\
\text { Community+ } \\
\text { Non-governmental } \\
\text { organizations }\end{array}$ & $\begin{array}{l}\text { The community involving } \\
\text { pattern takes the collective } \\
\text { community as the main } \\
\text { body; community sets up } \\
\text { joint-stock enterprises; the } \\
\text { community residents are } \\
\text { actively involved in the } \\
\text { project development, finally } \\
\text { non-governmental society } \\
\text { organizations provide the } \\
\text { corresponding technical } \\
\text { support and aid. }\end{array}$ & $\begin{array}{l}\text { The rural ecological tourism } \\
\text { community fully reflects } \\
\text { from the sovereign. The } \\
\text { tourism project development } \\
\text { and planning are entirely } \\
\text { independent on the } \\
\text { community, and related } \\
\text { market profit distribution is } \\
\text { performed by community } \\
\text { residents; At the same time, } \\
\text { the model also can maximize } \\
\text { the protection of local } \\
\text { ecological environment. } \\
\text { However, community } \\
\text { economy and social } \\
\text { development level are } \\
\text { modest. }\end{array}$ & $\begin{array}{lr}\text { Diqing } & \text { Hama } \\
\text { valley } & \text { in } \\
\text { Yunnan } & \\
\text { province } & \text { in } \\
\text { China } & \end{array}$ \\
\hline $\begin{array}{lr}\text { Travel }+ & \text { Rural } \\
\text { tourism } & \\
\text { association } & + \\
\text { Company } & + \\
\text { Government } & \end{array}$ & $\begin{array}{l}\text { The local government } \\
\text { community participation } \\
\text { model is in charge of the } \\
\text { whole part of the overall } \\
\text { planning, as well as the } \\
\text { corresponding infrastructure } \\
\text { construction; travel company } \\
\text { shall be responsible of the } \\
\text { most basic business } \\
\text { management activity, and } \\
\text { farmers tourism association } \\
\text { organizes community } \\
\text { residents into the } \\
\text { consultation mechanisms of } \\
\text { farmers interests } \\
\text { participation in the company, } \\
\text { and the travel agent is } \\
\text { responsible for organization }\end{array}$ & $\begin{array}{l}\text { The most significant point of } \\
\text { the mode is that community } \\
\text { residents directly involve in } \\
\text { the development of tourism } \\
\text { projects, decision-making, } \\
\text { production, management and } \\
\text { other activities; Between } \\
\text { community residents and } \\
\text { businesses, there are } \\
\text { common target market and } \\
\text { economic benefits; it can } \\
\text { enhance the local ecological } \\
\text { tourism brand image. }\end{array}$ & $\begin{array}{l}\text { PingBa county } \\
\text { Tianlongtun in } \\
\text { Guizhou } \\
\text { province in } \\
\text { China }\end{array}$ \\
\hline
\end{tabular}




\begin{tabular}{|l|l|l|l|}
\hline & $\begin{array}{l}\text { and finding market } \\
\text { customers. }\end{array}$ & & \\
\hline
\end{tabular}

III. THE CHOICE, DETERMINATION AND USE OF RURAL TOURISM COMMUNITY PARTICIPATION PATTERN

Table 2-1 presents the current existing domestic rural ecological tourism community participation models, which are the market products under specific social and historical environment, including the necessity of The Times, also the real rationality of market demand with a certain degree of limitation of historical development. Therefore, the rural ecological tourism community participation pattern choice, determination should be based on the community actual development specific conditions and market objective reality, scientifically follow the basic situation of local practice, combining with the above mentioned rural ecological tourism community participation model choice target, selection principles, and make targeted mode choices respectively under different stages of link in different developing regions.

A. Create rural Eco-tourism community participation benefit sharing mechanism

Rural Eco-tourism community has development personality. In the early last century, Murphy has proposed his own view "to carry out and develop tourism industry in residents community, the host of the traditional industries must be voluntary partners". In my understanding, the meaning of this essentially expounds the basic goals of rural Eco-tourism and the final development goal, and its basic goal is to protect the ecological environment; the final purpose is to promote the comprehensive development of the local community (including culture, economy, education, tourism, etc.).

B. Actively build effective community participation coordination system

About the improvement and implementation of rural ecological tourism community participation model, the rural ecological tourism community participation pattern has been mentioned above, in fact, mainly pay more attention to economic benefits and tourism project output efficiency, and its fundamental purpose and aim embodies the basic choice principle of "people-oriented, serve people". Among them, rural communities, non-governmental organizations, enterprises, government are the main body of each link, but the most fundamental subject is countryside community residents. The improvement of rural ecological tourism community participation pattern, therefore, is consistent to the choice of basic principles. Further study community management mechanism, and perfect rural ecological tourism community participation model to solve the prominent contradictions and problems (see Table 2-1).

\section{CONCLUSION:}

One of the most critical middle links of rural ecological tourism community participation mode selection and implementation is community participation. Community participation is an important part of rural Eco-tourism development. In the process, maximize the regional practice of individuation development. As shown in Figure 2-1, in determined model framework, different subjects takes their responsibility in a fair and reasonable market interest coordination mechanism. With the continuous development and innovation of tourism industry, its defects and holes under the market mechanism will be more prominent as well as the enormous economic benefits, therefore, the rural ecological tourism community participation model in the Figure can properly build a benign operation of an open and transparent rural ecological tourism community public information management platform.

\section{REFERENCES}

[1] Cai Bifan, Tao Zhuomin, Lang Fuping. Rural tourism community participation pattern comparison research---- take three villages in Zhejiang province as an example [J]. Journal of Business Research, 2013, (10) : 191-196.

[2] Wu Ruihui. Rural tourism community participation mode selection and optimization [D]. Central South Forestry University of Science and Technology, 2013.

[3] Cheng Lianting. Hechi karst mountainous rural Eco-tourism development thinking [J]. Business, 
2015, (14) : 273-273266.

[4] Wang Yan, Sun Deliang, Zhang Junyi, etc. Guizhou rural ecological tourism development situation and countermeasures [J]. Journal of Guizhou Agricultural Science, 2013, 9 (6) : 221-225.

[5] Zhang Yu, Yan Lijiao, Xu Huan. Rural ecological tourism community participation model study---- Wufeng county for example [J]. Science and Technology, 2009, 25 (2) : 220-225.

[6] Chen Haiying, Zeng Xiaohong. Rural ecological tourism community participation pattern from stakeholder perspective ---- Haikou Squama village for example [J]. Journal of Guangdong Agricultural Science, 2011, 38 (14) : 157-160. 